\title{
GA $_{3}$ Application Alters Flowering Phenology of 'Hass' Avocado
}

\author{
Samuel Salazar-García ${ }^{1}$ and Carol J. Lovatt ${ }^{2}$ \\ Department of Botany and Plant Sciences, University of California, Riverside, CA 92507-0124
}

\begin{abstract}
ADmTIONAL IndEX woRds. Persea americana, determinate inflorescence, flowering inhibition, indeterminate inflorescence, inflorescence development

Anstract. The objectives of the present research were to quantify 1) the contribution that vegetative shoots produced in the summer vs. fall and indeterminate vs. determinate inflorescences make to yield and 2) the effects of $\mathrm{GA}_{3}$ on flowering expression and inflorescence phenology of summer and fall shoots of 'Hass' avocado (Persea americana Mill.) under field conditions. Anthesis started earlier on fall than summer shoots of 10-year-old 'Hass' avocado trees; however, no difference in the date of full bloom was observed. Indeterminate inflorescences that underwent early anthesis set more fruit than those with delayed anthesis, conversely, determinate inflorescences with delayed anthesis set more fruit. Indeterminate inflorescences comprised $90 \%$ of total inflorescences and contributed $73 \%$ of total fruit yield, but individual determinate inflorescences were at least three times more productive than the indeterminate ones. Summer and fall shoots were sprayed with $0,50,100$, or $1000 \mathrm{mg} \cdot \mathrm{L}^{-1} \mathrm{GA}_{3}$ in November, December or January. $\mathrm{GA}_{3}$ stimulated apical growth of all shoots. If secondary axes of an inflorescence bud were differentiated at the time of $\mathrm{GA}_{3}$ application, the inflorescence developed in advance of inflorescences on branches not treated with $\mathrm{GA}_{3}$. In addition, $\mathrm{GA}_{3}$ caused precocious development of the vegetative shoot of indeterminate inflorescences relative to the flowers in the same inflorescence and relative to the vegetative shoot of indeterminate inflorescences from untreated branches. Stimulation of vegetative growth at the inflorescence apex by $\mathrm{GA}_{3}$ inhibited growth of axillary buds. $G A_{3}$ at $50 \mathrm{mg} \cdot \mathrm{L}^{-1}$ had no effect on the number of determinate or indeterminate inflorescences produced by either summer or fall shoots. Higher concentrations of $\mathbf{G A}_{3}$ increased the number of vegetative shoots and inactive buds produced by both shoot types.
\end{abstract}

Avocado trees generally produce two or three vegetative flushes during the year (i.e., spring, summer, and fall flushes). Not all the branches contribute to each flush (Davenport, 1982; Scholefield et al., 1985; Venning and Lincoln, 1958). Spring flush shoots can produce either summer or fall flush vegetative shoots. Shoots produced early in the summer can contribute to the fall vegetative flush, but late summer shoots typically produce inflorescences during the winter-spring flowering period (Thorp et al., 1993). Fall shoots that developed early (September in the Northern hemisphere) may flower immediately during the winter-spring bloom period; other fall flush shoots contribute to the spring vegetative flush. The proportion of summer and fall vegetative apices that continue the growth of the shoot or develop into inflorescences is unknown.

'Hass' avocado trees have a profuse and extended flowering period. Flowering, which may start early in the winter (January), continues throughout most of the spring season, with peak bloom occurring between March and May under Southern California conditions (Lovatt, 1990). As bloom progresses, competition with the developing spring flush increases. This competition is intense in indeterminate inflorescences, in which the vegetative apex starts

Received for publication 16 Sept. 1997. Accepted for publication 4 May 1998. This research was supported in part the Citrus Research Center and Agricultural Experiment Station of the Univ. of California, Riverside and by the California Avocado Commission. This paper represents a portion of the dissertation submitted by S.S.-G. in partial fulfillment of requirements for a $\mathrm{PhD}$ in Botany at the Univ. of California. S. S-G. acknowledges the financial support of CONACYT, INIFAP and SNI of Mexico and the University of California, Riverside. We thank Charlie W. Coggins, Jr., for his advice on the selection of $\mathrm{GA}_{3}$ concentrations and for his critical revicw of the manuscript. We thank Abbott Laboratories for donating the Progibb and Dick Whiley for access to his avocado orchards in Rancho California. The cost of publishing this paper was defrayed in part by the payment of page charges. Under postal regulations, this paper therefore must be hereby marked advertisement solely to indicate this fact.

'Current address: Campo Experimental Santiago Ixcuintla-INIFAP, Apdo. Postal 100, Santiago Ixcuintla, NAY 63300, Mexico; to whom reprint requests should be addressed.

${ }^{2}$ Professor of plant physiology. growing after inflorescence elongation and the vegetative shoot continues expanding during anthesis and fruit set (Bower and Cutting, 1992; Cutting and Bower, 1990; Whiley, 1990; Zilkah et al., 1987). Singularly and in combination, these factors may reduce fruit set. Manipulation of avocado flowering to change these relationships temporally may help to increase fruit set and yield.

Exogenous application of gibberellins (especially $\mathrm{GA}_{3}$ ) might provide a tool to manipulate time and intensity of flowering. $\mathrm{GA}_{3}$ application has been shown to inhibit flower initiation in both deciduous (Sedgley, 1990) and subtropical fruit crops, such as lemon (Nir et al., 1972), mandarins (Iwahori and Oohata, 1981) and orange (Guardiola et al., 1977). Similar responses to $\mathrm{GA}_{3}$ have been found in tropical fruit crops. The time of $\mathrm{GA}_{3}$ application influences the response. For example, application of $\mathrm{GA}_{3}$ to apical buds of mango (Mangifera indica L. 'Dashehari') before floral initiation stimulated vegetative growth in $75 \%$ of shoots. However, once floral meristems were present, $\mathrm{GA}_{3}$ did not inhibit flowering (Kachru et al., 1972). In another case, $\mathrm{GA}_{3}$ treatment repressed floral bud initiation of 'Keitt' mango and delayed flowering by $>4$ weeks (Nunez-Elisea and Davenport, 1991). Porlingis and Boynton (1961) found a dual effect of $\mathrm{GA}_{3}$ on strawberry (Fragaria chiloensis) flowering. $\mathrm{GA}_{3}$ accelerated the appearance of flowers that had differentiated at the time of application but inhibited the initiation of new flowers under inductive conditions. In coffee (Coffea arabica L.), the effect of $\mathrm{GA}_{3}(100$ $\mathrm{mg} \cdot \mathrm{L}^{-1}$ ) was also dependent on the stage of floral bud development (Schuch et al., 1990).

The goal of the present research was to determine whether $\mathrm{GA}_{3}$ applied to the canopy of 'Hass' avocado might have potential as a management tool to increase yield. Thus, this research had the following objectives: 1) to determine the time of flowering of vegetative shoots produced during the summer vs. fall flush; 2) to examine if the time of anthesis affects fruit set; 3 ) to quantify which type of inflorescence (determinate vs. indeterminate) contributes more to yield, and 4) to quantify the effects of dose and time of application of $\mathrm{GA}_{3}$ on inflorescence number and phenology. 


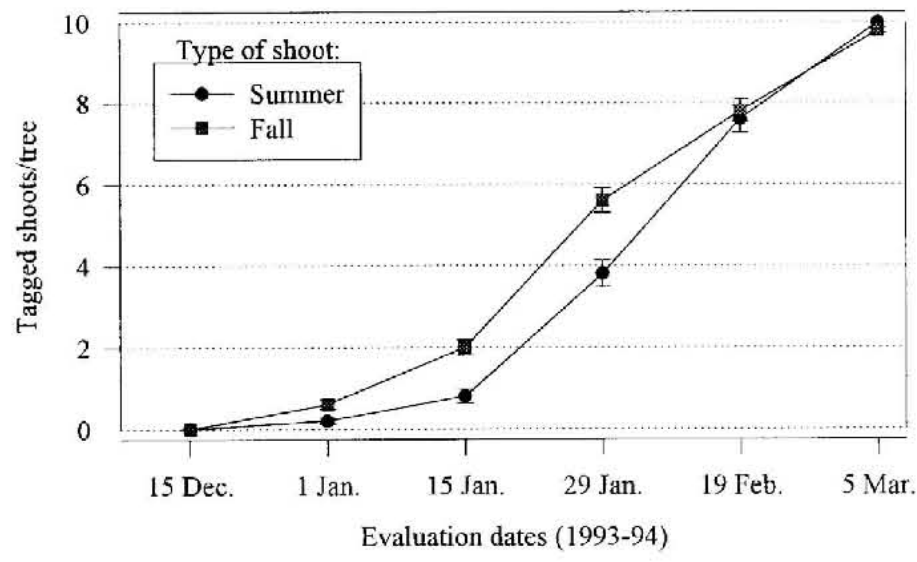

Fig. 1. Number of summer and fall 'Hass' avocado shoots at the stage of anthesis of first flowers. Each point is a mean \pm SE of 20 trees and 10 shoots per tree.

\section{Materials and Methods}

The research was conducted in a commercial 'Hass' avocado orchard in Rancho California (Southern California, lat. $33^{\circ} \mathrm{N}$ ) from 1993 to 1995 . Avocado trees planted at a spacing of $7 \times 7 \mathrm{~m}$ on a south oriented hill were used. Water and nutritional management were standard grower practices and no visual symptoms of water stress or nutritional disorders were observed.

TIME OF ANTHESIS IN 1994 FOR APICAL INFLORESCENCES OF 1993 SUMMER AND FALL FluSh SHOOTs. Twenty 10 -year-old 'Hass' avocado trees that set no fruit during spring bloom 1993 were selected (block 1). In each tree, 10 shoots that developed during Summer 1993 and 10 that developed during Fall 1993 were tagged. For each shoot, the number of inflorescences with flowers at anthesis were quantified throughout the 1994 flowering season.

EFFECT OF GA AN $_{3}$ FLOWERING OF 1993 SUMMER AND FALL FLUSH shoots. Thirty 10-year-old 'Hass' avocado trees were used during 1993-94 (block 2). To avoid a possible effect of fruit load on flowering, branches, each at a similar phenological stage and with no fruit set from the 1993 spring bloom were chosen in September 1993. On the south side of each tree (developmentally the most advanced and uniform), four branches $1 \mathrm{~m}$ in length were selected and their shoots tagged according to the vegetative flush in which they developed (summer or fall). For each shoot, the apical bud and its five immediate axillary buds were tagged. For $\mathrm{GA}_{3}$ treatments, a fresh solution of $\mathrm{GA}_{3}$ prepared from Progibb 4\% (Abbott Laboratories, North Chicago) plus $1 \mathrm{~mL} \cdot \mathrm{L}^{-1}$ Triton $\mathrm{X}-100$ (Sigma Chemicals, St. Louis) in water (pH 5.5) was sprayed onto selected branches until runoff. Treatments consisted of a single application of one of four $\mathrm{GA}_{3}$ concentrations $\left(0,50,100\right.$, and $1000 \mathrm{mg} \cdot \mathrm{L}^{-1}$ ) and three spray dates, the 13th day of either November 1993, December 1993, or January 1994. All treatments were sprayed before budbreak. Control branches received only water plus Triton $\mathrm{X}-100$ ). To determine the stage of inflorescence bud development at each spray date, the apical bud of one summer and one fall shoot per replication were collected. Buds were immediately fixed in FAA ( 5 formalin : 5 acetic acid : 90 ethanol, by volume), dehydrated, infiltrated, embedded, sectioned, and stained as described by Salazar-García et al. (1998). The type of growth produced by apical and axillary buds, and inflorescence phenological stage were recorded for individual shoots. Developmental stages were evaluated according to the macro- and microscopic analysis of Salazar-García et al. (1998). A randomized complete block design with 10 individual tree replications was used. Percentages of the total number of shoots were transformed by arcsin of the square root of the percentage prior to statistical analysis (Steel and Torrie, 1980). For means comparison, the Duncan's multiple range test was used. When a two means comparison was needed, an F test was performed before the $t$ test.

Fruit SET ON EARLY AND LATE SEASON INFLORESCENCES (1994). Fifty-nine 10-year-old 'Hass' avocado trees (block 3) with regular fruit load ( 30 to $80 \mathrm{~kg} /$ tree) were used. In each tree, two groups of 50 apical inflorescences at Stage 8 of development (cauliflower stage) (Salazar-García et al., 1998) were tagged in an uniform manner around the tree. The first cohort (early inflorescences) was tagged on 12 Feb. 1994. The second one (late inflorescences) was selected a month later (12 Mar.). Fruit set by determinate and indeterminate inflorescences was recorded after the June fruit drop period on 8 Aug. 1994. A second evaluation was done on $8 \mathrm{Dec}$. 1994 when fruit reached physiological maturity and were close to harvest. Experimental layout and data analysis for this and the next study were performed in the same way. A randomized block design with 59 individual tree replications was used. Before statistical analysis the data were transformed by the square root of the observation plus one.

Productivity OF DETERMINATE AND INDETERMINATE INFLoRESCENCES (1995). This research was conducted in block 3 used above. At the beginning of this evaluation (spring 1995) all trees were in their "off" crop year and were bearing little to no fruit. Flowering

Table 1. Stage of inflorescence development of apical buds of summer and fall shoots of 'Hass' avocado at the time of $\mathrm{GA}_{3}$ treatment.

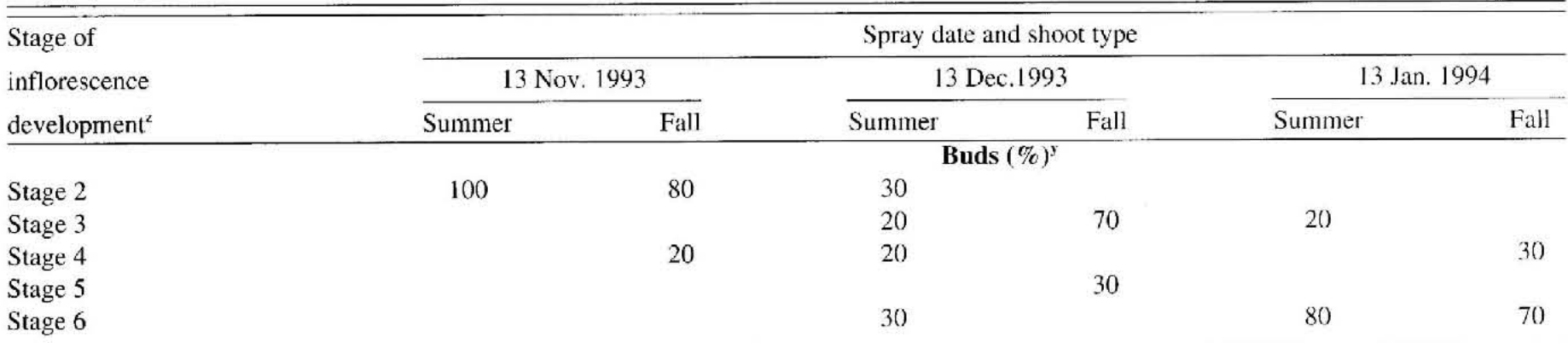

${ }^{{ }^{7}}$ Stages of inflorescence development (Salazar-García et al., 1998). 1 = Convex primary axis meristem with bracts. One or two secondary axis meristems in the axil of bracts. $2=$ Flat primary axis meristem with separated bracts. One to three secondary axis meristems in the axils of bracts. $3=$ Convex primary axis meristem. Four secondary axis inflorescence meristems. 4 = Flat primary axis meristem. Ten secondary axis inflorescence meristems. $5=$ Elongation of oldest secondary axis in with tertiary axis meristems present. Initial development of perianth of terminal flowers of secondary and tertiary axes. 6 = Elongation of youngest secondary axis meristems. Oldest secondary axes are completely formed, including cyme of flowers. Flowers have complete perianth, and anthers with sporogenous tissue are present. Gynoecium is at early locule formation.

y Obtained from median longitudinal sections of 10 buds per shoot type and 10 tree replications for each sampling date. 
Table 2. Apical growth produced by 'Hass' avocado branches sprayed with $\mathrm{GA}_{3}$ on 13 Nov. 1993.

\begin{tabular}{|c|c|c|c|}
\hline \multirow{2}{*}{$\begin{array}{l}\text { Shoot type and } \\
\mathrm{GA}_{3}\left(\mathrm{mg} \cdot \mathrm{L}^{-1}\right)\end{array}$} & \multicolumn{3}{|c|}{ Total shoots $(\%)$} \\
\hline & Inflorescences & Vegetative shoots & Inactive buds \\
\hline \multicolumn{4}{|l|}{ Summer shoots } \\
\hline 0 & $100.0 a^{\prime}$ & $0.0 \mathrm{c}$ & $0.0 \mathrm{a}$ \\
\hline 50 & $90.8 \mathrm{ab}$ & $9.2 \mathrm{c}$ & $0.0 \mathrm{a}$ \\
\hline 100 & $54.2 \mathrm{bc}$ & $33.3 \mathrm{~b}$ & $12.5 \mathrm{a}$ \\
\hline 1000 & $34.2 \mathrm{c}$ & $63.3 \mathrm{a}$ & $2.5 \mathrm{a}$ \\
\hline \multicolumn{4}{|l|}{ Fall shoots } \\
\hline 0 & $92.9 \mathrm{a}$ & $5.7 \mathrm{~b}$ & $1.4 \mathrm{a}$ \\
\hline 50 & $96.3 \mathrm{a}$ & $3.7 \mathrm{~b}$ & $0.0 \mathrm{a}$ \\
\hline 100 & $71.4 \mathrm{ab}$ & $14.3 \mathrm{~b}$ & $14.3 \mathrm{a}$ \\
\hline 1000 & $47.5 b$ & $50.0 \mathrm{a}$ & $2.5 a$ \\
\hline
\end{tabular}

was abundant since it was the beginning of the "on" cycle. In each tree, five branches $1 \mathrm{~m}$ long distributed around the tree were tagged. The total number of determinate and indeterminate inflorescences present in each branch was counted at the anthesis stage (11 Apr. 1995). In addition, the number of flowers per inflorescence was counted for a sample of four inflorescences per inflorescence type per tree. Because our 1994 study of fruit set showed no significant differences between the evaluations done after the June fruit drop period ( 8 Aug.) and final fruit set ( $8 \mathrm{Dec}$.), only fruit set at physiological maturity was quantified for this study $6 \mathrm{Dec}$. 1995). For data analysis at the branch level, the average of five branches per tree was used.

\section{Results}

TIME OF ANTHESIS IN 1994 FOR APICAL INFLORESCENCES OF 1993 SUMMER AND FALL FLUSH SHOOTS. Anthesis started in January and was first observed on fall shoots. By 19 Feb., eight out of ten summer and fall shoots had inflorescences at anthesis (Fig. 1). Inflorescences borne on fall shoots were mostly indeterminate in the apical position and few shoots produced axillary inflorescences. Summer shoots had a more intense production of apical and axillary inflorescences that reached anthesis almost simultaneously (data not shown).

EFFECT OF GA $_{3}$ ON FLOWERING OF 1993 SUMMER AND FALL FLUSH SHOOTS: STAGE OF INFLORESCENCE DEVELOPMENT OF APICAL BUDS OF SUMMER AND FALL SHOOTS AT THE TIME OF GA 3 TREATMENT. By 13 Nov. 1993, macroscopic development of apical buds on summer flush shoots showed pointed buds with closed bud scales, which corresponded to Stage 2 described by Salazar-García et al. (1998). Microscopic analysis of buds at this stage revealed a flat primary axis meristem with separated bracts in which one to three secondary axis meristems had already formed (Table 1). Organogenesis was monitored from November through January. On 13 Nov. apical buds on fall flush shoots had all reached Stage 2, but $20 \%$ had already progressed to Stage 4 , by which time all 10 secondary axis meristems of the inflorescence had formed. By 13 Dec. apical buds of summer and fall shoots presented a wide range of developmental stages with $30 \%$ of the apical buds on summer flush shoots advanced to Stage 6 . Externally, the buds were rounded with only bases of outermost scales remaining such that bracts enclosing the inflorescence were visible. Microscopic analysis showed that the youngest secondary axis meristems were elongated and that the oldest basal secondary axes were completely formed, including the terminal cyme of flowers. The flowers had a complete perianth and anthers with sporogenous tissue evident. The gynoecium was at the stage of early locule formation (Salazar-García et al., 1998). By $13 \mathrm{Jan} .,>70 \%$ of the apical buds on shoots of either age were at Stage 6 (Table 1) and thus had not reached budbreak.

RESPONSE OF INFLORESCENCE BUDS TO GA $\mathrm{GR}_{3}$ TREATMENT. Increasing concentrations of $\mathrm{GA}_{3}$ applied to summer and fall flush shoots in November reduced the production of inflorescences with a concomitant increase in vegetative shoot production (Table 2). Control summer shoots produced only inflorescences $(100 \%$ of total shoots), whereas summer shoots sprayed with either 100 or $1000 \mathrm{mg} \cdot \mathrm{L}^{-1} \mathrm{GA}_{3}$ in November had fewer inflorescences. In contrast, $\mathrm{GA}_{3}$ at $1000 \mathrm{mg} \cdot \mathrm{L}^{-1}$ decreased the production of inflorescences and increased the production of vegetative shoots from apical buds on fall shoots (Table 2). Later $\mathrm{GA}_{3}$ sprays in December or January did not affect the type of growth produced (vegetative or reproductive) by apical buds of either summer and fall shoots. In addition, at the later application dates, $\mathrm{GA}_{3}$ sprays did not have a consistent effect on the proportion of apical buds that remained inactive. This proportion, compared to control, was significantly increased $(P=0.10)$ only by $\mathrm{GA}_{3}$ at $1000 \mathrm{mg} \cdot \mathrm{L}^{-1}$ in December, causing $8.3 \%$ of the apical buds of summer shoots to remain inactive (data not shown).

EFFECT OF GA $A_{3}$ ON THE PRODUCTION OF DETERMINATE AND INDETERMINATE INFLORESCENCES BY APICAL BUDS. Untreated apical buds (control) on both summer and fall flush shoots produced more indeterminate than determinate inflorescences in the two blocks in this study. Production of indeterminate inflorescences by control summer shoots ranged from $50 \%$ to $58 \%$ of total shoots, whereas determinate inflorescences ranged from $39 \%$ to $50 \%$ (Table 3 ). Fall shoots always produced a higher proportion of indeterminate inflorescences $(50 \%$ to $70 \%$ ) and a lower proportion of determinate inflorescences ( $24 \%$ to $40 \%$ ). For summer shoots, the production of determinate inflorescences was significantly reduced when 100 or $1000 \mathrm{mg} \cdot \mathrm{L}^{-1} \mathrm{GA}_{3}$ was applied in either November or December (Table 3 ). Number of determinate inflorescences on fall shoots was reduced only when $\mathrm{GA}_{3}$ was applied in November. In general, $\mathrm{GA}_{3}$ application, even at the highest concentration was without significant effect on the production of indeterminate inflorescences for most treatment dates, except for December and January for which significant increases in the number of indeterminate inflorescences resulted (Table 3).

EFFECT OF GA 3 ON AXILLARY BUDS. GA 3 treatment consistently caused a decrease in the production of inflorescences and an increase of the number of inactive buds borne in axillary position on summer shoots. This effect increased with increasing $\mathrm{GA}_{3}$ concentrations. For summer shoots, growth of axillary buds was totally inhibited only with $\mathrm{GA}_{3}$ at $1000 \mathrm{mg} \cdot \mathrm{L}^{-1}$ applied in Novem- 


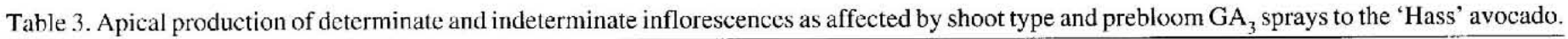

\begin{tabular}{|c|c|c|c|c|c|c|}
\hline \multirow{3}{*}{$\begin{array}{l}\text { Shoot type and } \\
\mathrm{GA}_{3}\left(\mathrm{mg}^{-1}\right)\end{array}$} & \multicolumn{6}{|c|}{ Spray date and type of inflorescence } \\
\hline & \multicolumn{2}{|c|}{13 Nov. 1993} & \multicolumn{2}{|c|}{13 Dec. 1993} & \multicolumn{2}{|c|}{13 Jan. 1994} \\
\hline & Determinate & Indeterminate & Determinate & Indeterminate & Determinate & Indeterminate \\
\hline & \multicolumn{6}{|c|}{ Total shoots $(\%)$} \\
\hline \multicolumn{7}{|l|}{ Summer shoots } \\
\hline 0 & $49.6 \mathrm{a}^{2}$ & $50.4 \mathrm{a}$ & $39.4 \mathrm{a}$ & $58.1 \mathrm{~A}$ & $45.8 \mathrm{a}$ & $54.2 \mathrm{a}$ \\
\hline 50 & $40.6 \mathrm{a}$ & $50.2 \mathrm{a}$ & $38.7 \mathrm{ab}$ & $56.3 \mathrm{~A}$ & $11.9 \mathrm{a}$ & $66.7 \mathrm{a}$ \\
\hline 100 & $10.0 \mathrm{~b}$ & $44.2 \mathrm{a}$ & $8.1 \mathrm{bc}$ & $84.4 \mathrm{~B}$ & $36.9 \mathrm{a}$ & $58.3 \mathrm{a}$ \\
\hline 1000 & $0.0 \mathrm{~b}$ & $34.2 \mathrm{a}$ & $0.0 \mathrm{c}$ & $83.3 \mathrm{~B}$ & $43.8 \mathrm{a}$ & $31.2 \mathrm{a}$ \\
\hline \multicolumn{7}{|l|}{ Fall shoots } \\
\hline 0 & $24.1 \mathrm{~A}$ & $68.8 \mathrm{ab}$ & $30.0 \mathrm{a}$ & $70.0 \mathrm{~B}$ & $40.0 \mathrm{a}$ & $50.0 \mathrm{~B}$ \\
\hline 50 & $8.3 \mathrm{AB}$ & $88.0 \mathrm{a}$ & $5.7 \mathrm{a}$ & $94.3 \mathrm{~A}$ & $0.0 \mathrm{a}$ & $76.7 \mathrm{AB}$ \\
\hline 100 & $1.6 \mathrm{~B}$ & $69.8 \mathrm{ab}$ & $16.6 \mathrm{a}$ & $77.8 \mathrm{AB}$ & $0.0 \mathrm{a}$ & $100.0 \mathrm{~A}$ \\
\hline 1000 & $5.0 \mathrm{~B}$ & $42.5 \mathrm{~b}$ & $0.0 \mathrm{a}$ & $83.3 \mathrm{AB}$ & $11.9 \mathrm{a}$ & $73.8 \mathrm{AB}$ \\
\hline
\end{tabular}

${ }^{7}$ Mean separation in columns for each shoot by Duncan's multiple range test, $P=0.05$ (lowercase letters) and 0.10 (uppercase letters).

ber and December (Fig. 2). Axillary buds on untreated fall shoots (control) did not reach budbreak; this situation was not changed by $\mathrm{GA}_{3}$ treatment (data not shown). Due to the greater number of axillary inflorescences produced by summer shoots, flowering was more intense than that of fall shoots. All axillary buds that developed produced only determinate inflorescences.

EFFECT OF GA ON $_{3}$ ON THE RATE OF INFLORESCENCE BUD DEVELOPMENT. By 13 Jan., control branches had no inflorescences at the cauliflower stage (Stage 8; Salazar-García et al., 1998), which is easily distinguished by elongation of secondary axes and the presence of small closed flowers on the tertiary axes, but branches sprayed with $50 \mathrm{mg} \cdot \mathrm{L}^{-1} \mathrm{GA}_{3}$ in November or December had $8 \%$ and $18 \%$ of total inflorescences at the cauliflower stage, respectively (Fig. 3). A more advanced flowering was obtained with $\mathrm{GA}_{3}$ at $100 \mathrm{mg} \cdot \mathrm{L}^{-1}$ applied in November or December, where $71 \%$ and $25 \%$ of total inflorescences were at the cauliflower stage by $13 \mathrm{Jan}$. By the same evaluation date, branches treated with $\mathrm{GA}_{3}$ at 1000 $\mathrm{mg} \cdot \mathrm{L}^{-1}$ in either November or December had $\approx 80 \%$ of total inflorescences at this stage (Fig. 3). Inflorescence development was also increased with the January $\mathrm{GA}_{3}$ application, the effect of which was clearly observed only 14 d later. By 27 Jan., only $23 \%$ of total inflorescences produced from the apical bud of summer and fall shoots (pooled data) not treated with $\mathrm{GA}_{3}$ had reached the cauliflower stage, whereas $80 \%$ of those shoots treated with 50 or $100 \mathrm{mg} \cdot \mathrm{L}^{-1} \mathrm{GA}$ on $13 \mathrm{Jan}$. had reached this stage. All shoots treated with $\mathrm{GA}_{3}$ reached this stage earlier than the control. Earlier spray dates, like November and December, and higher concentrations had the most striking effects (Fig. 3).

The date by which $50 \%$ of total inflorescences reached the cauliflower stage was calculated for control and $\mathrm{GA}_{3}$ treatments (data not shown). $\mathrm{GA}_{3}$ at $50 \mathrm{mg} \cdot \mathrm{L}^{-1}$ sprayed either in December or January caused inflorescence development to be $23 \mathrm{~d}$ ahead of the control. $\mathrm{G} \Lambda_{3}$ at $100 \mathrm{mg} \cdot \mathrm{L}^{-1}$ in either November or December caused the cauliflower stage to occur 37 and 23 d earlier than the control, respectively. Cauliflower stage also was advanced $37 \mathrm{~d}$ with $\mathrm{GA}_{3}$ at $1000 \mathrm{mg} \cdot \mathrm{L}^{-1}$ applied in November or December and 23 $\mathrm{d}$ when applied in January. Although $\mathrm{GA}_{3}$-treated shoots reached the cauliflower stage earlier, anthesis was not earlier.

EFFECTS OF $\mathrm{GA}_{3}$ ON VEGETATIVE SHOOT DEVELOPMENT OF INDETERMINATE INFLORESCENCES. For indeterminate inflorescences developing at the apex of either untreated (control) summer or fall flush shoots, vegetative shoot growth and subsequent leaf expansion were delayed relative to elongation of the secondary axes of the inflorescence (Fig. 4). Thus, by 5 Mar. 1994, when almost
$100 \%$ of total inflorescences of the control had reached the cauliflower stage, or a later stage of development, (Fig. 3), only $11 \%$ had initiated the first leaves of their vegetative shoot apex (Fig. 5). $\mathrm{GA}_{3}$ sprays altered normal inflorescence phenology and caused the vegetative shoot to develop precociously and thus, simultaneously with elongation of the secondary and tertiary axes of the inflorescence (Fig. 4). An evaluation done on 5 Mar. 1994, showed that $\mathrm{GA}_{3}$ at 100 and $1000 \mathrm{mg} \cdot \mathrm{L}^{-1}$ applied in November, December or January caused significant precocious development of the vegetative shoot (Fig. 5). Late application dates (December and January) provided a greater response for all $\mathrm{GA}_{3}$ concentrations, including $50 \mathrm{mg} \cdot \mathrm{L}^{-1}$. GA $\mathrm{A}_{3}$ treatment with 100 or $1000 \mathrm{mg} \cdot \mathrm{L}^{-1}$ in either November or December caused shoot development to be initiated $37 \mathrm{~d}$ earlier than in the control (data not shown).

RELATIVE PRODUCTIVITY OF FARLY VS. LATE SEASON DETERMINATE AND INDETERMINATE INFLORESCENCES $(1994,1995)$. Early inflorescences (those that reached the cauliflower stage by $12 \mathrm{Feb}$. 1994; Stage 8 of the scale of Salazar-García et al., 1998) were predominantly located in the quadrant of the tree most exposed to the sun (SW). Late inflorescences, which reached the cauliflower stage by 12 March, were located in the NE quadrant. The number of
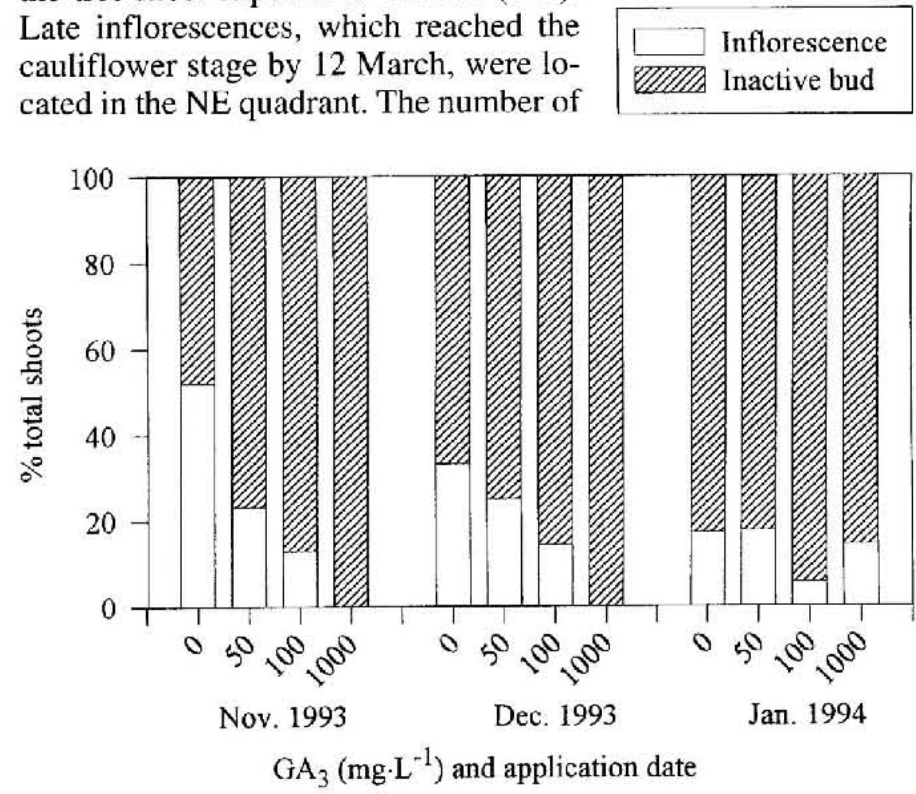

Fig. 2. Flowering response of axillary buds of 'Hass' avocado summer shoots sprayed with $\mathrm{GA}_{3}$ at different dates. Evaluation date: 26 Mar. 1994. All new growth consisted of determinate inflorescences. 

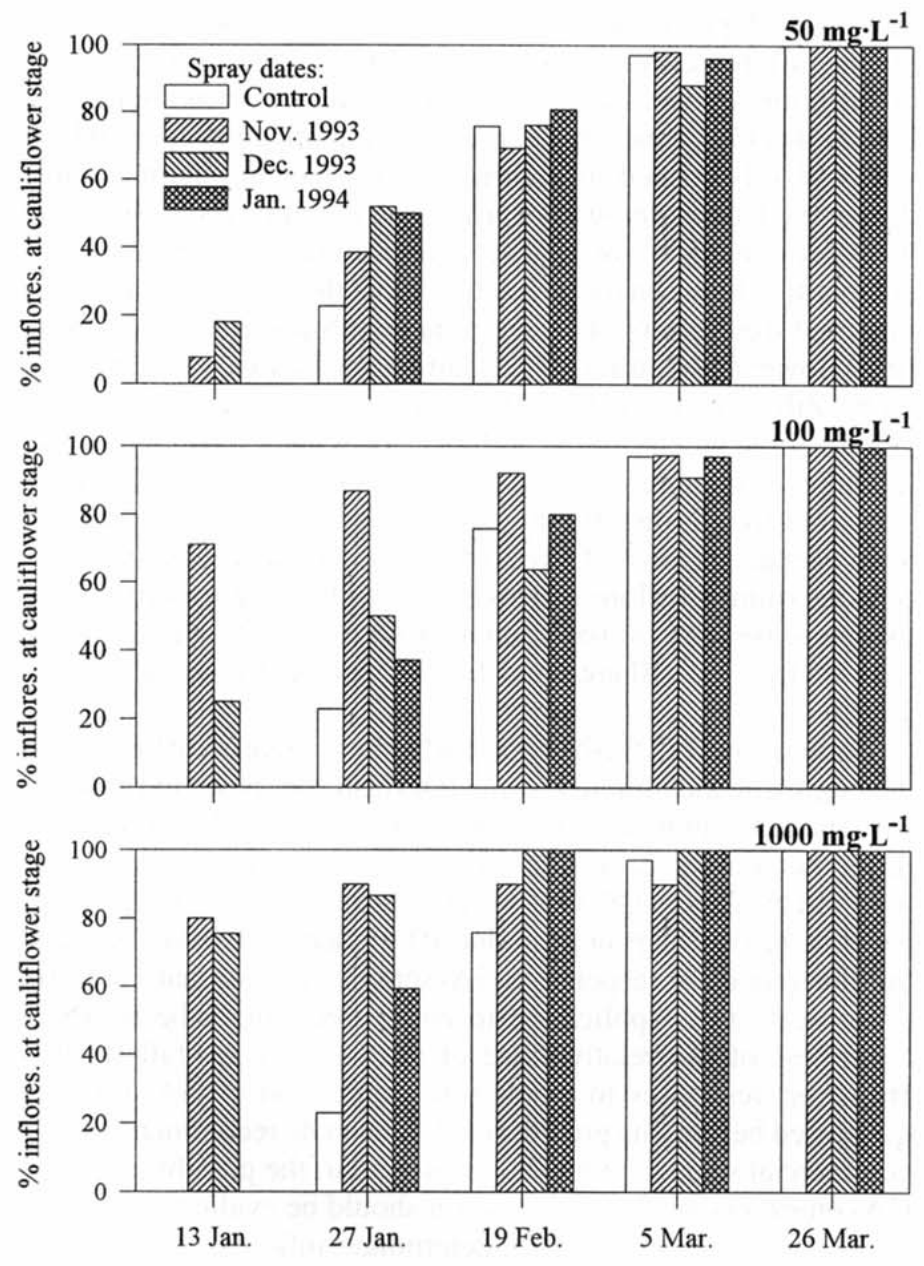

Evaluation dates (1994)

Fig. 3 (above). Percent apical inflorescences at the cauliflower stage (Stage 8; Salazar-García et al., 1998) in 'Hass' avocado shoots (pool of summer and fall shoots) as affected by spray date and $\mathrm{GA}_{3}$ concentrations. days from the cauliflower stage to anthesis was longer for early than for the late cohort of inflorescences. Early inflorescences that were mainly borne on fall shoots underwent anthesis on $\approx 12 \mathrm{Mar}$. Late inflorescences took only three weeks to advance from the cauliflower stage to anthesis, with anthesis occurring 2 Apr. 1994.

No significant differences on fruit set due to time of anthesis were detected at the end of the June drop period or at physiological maturity (Table 4). However, fruit set by early or late developing determinate vs. indeterminate inflorescences was significantly affected by time of anthesis. Determinate inflorescences were more productive when they developed later in the season (Table 5); whereas indeterminate inflorescences set more fruit when they developed earlier in the season.

The results of the second year study showed that indeterminate inflorescences were predominant, representing $\approx 90 \%$ of all inflorescences produced (Table 6) and yielded $73 \%$ of total fruit harvested. However, individual determinate inflorescences were three times more productive than the indeterminate ones. The number of flowers per determinate vs. indeterminate inflorescences was not significantly different (Table 6).

\section{Discussion}

$\mathrm{GA}_{3}$ sprays caused precocious development of inflorescence buds and vegetative apices of indeterminate inflorescences in 'Hass' avocado, which resulted in early budbreak and inflorescence elongation. Even at a low concentration $\left(50 \mathrm{mg} \cdot \mathrm{L}^{-1}\right)$, when $\mathrm{GA}_{3}$ was applied in December or January, $50 \%$ of the inflorescences reached the cauliflower stage 23 dearlier than the non- $\mathrm{GA}_{3}$ sprayed controls. Higher $\mathrm{GA}_{3}$ concentrations further accelerated the rate at which buds reached the cauliflower stage, but the date of anthesis was not significantly affected. This response is not undesirable, however, early budbreak might present the risk of

Fig. 4 (below). Precocious vegetative shoot development of indeterminate inflorescences on 'Hass' avocado summer shoots sprayed with $\mathrm{GA}_{3}$ in December 1993. From left to right, $0,50,100$, and $1000 \mathrm{mg} \cdot \mathrm{L}^{-1} \mathrm{GA}_{3}$. Picture taken on $5 \mathrm{Mar}$. 1994. $\mathrm{Bar}=30 \mathrm{~mm}$.

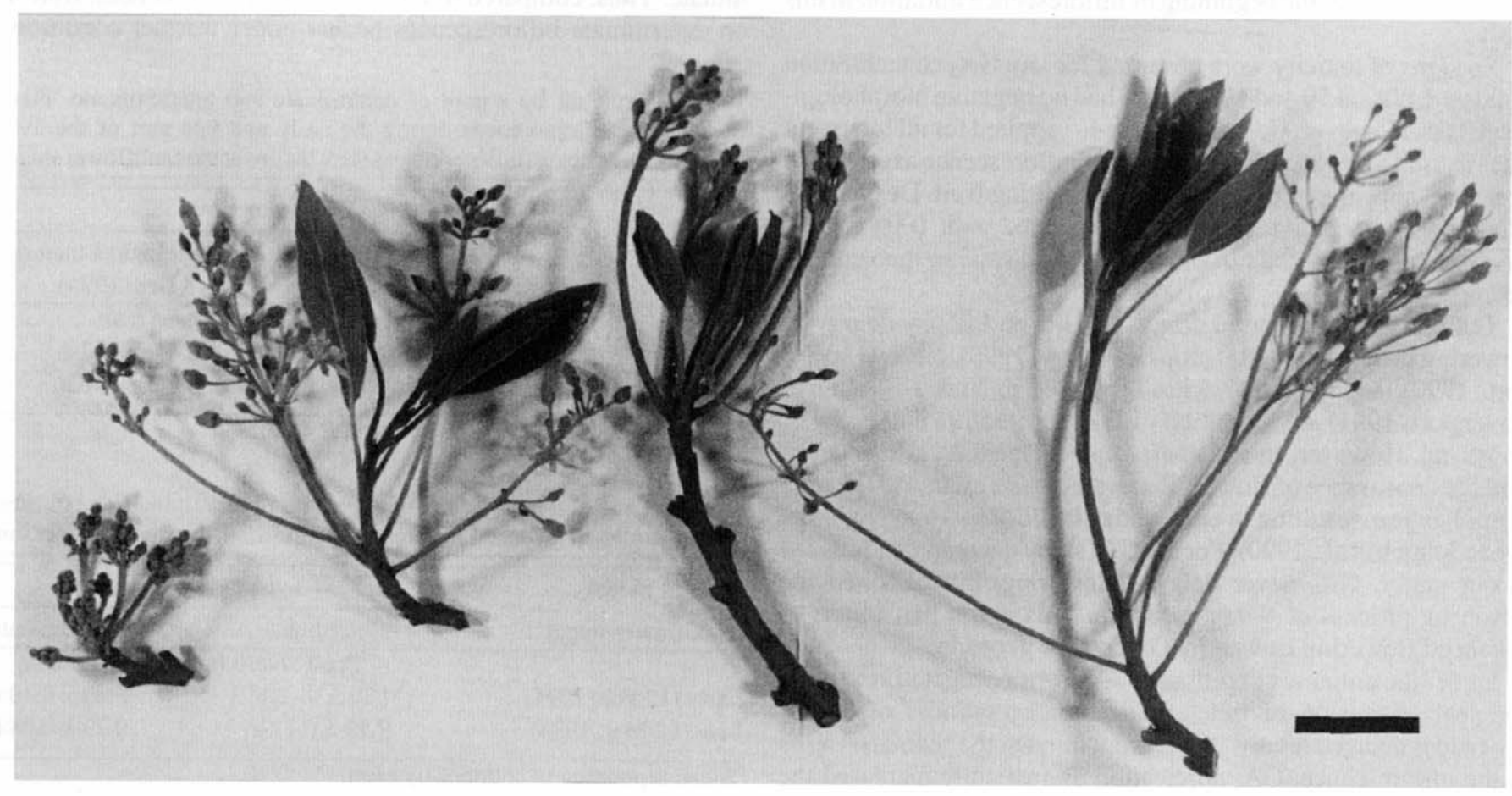




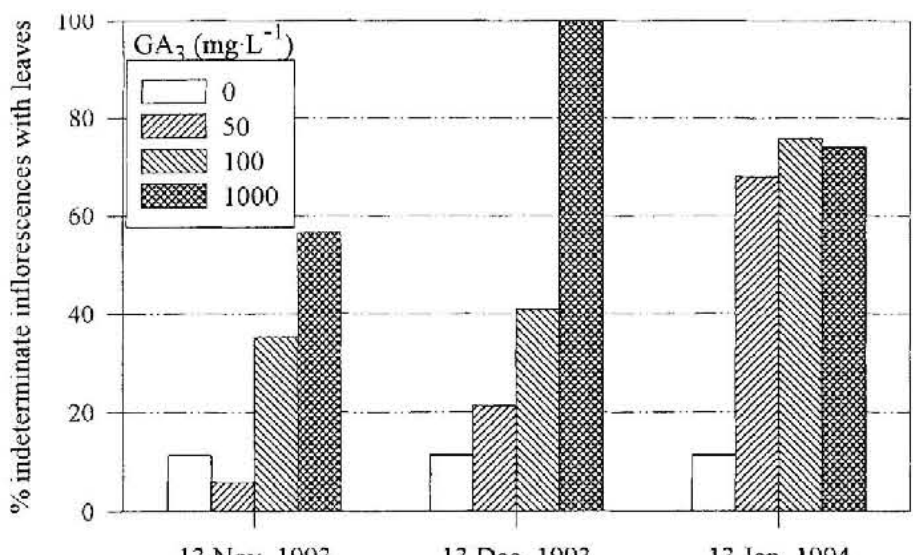

13 Nov 1993

13 Dec. 1993

13 Jan. 1994

Spray dates

Fig. 5. Precocious vegetative shoot development of indeterminate inflorescences of 'Hass' avocado shoots (pool of summer and fall shoots) as influenced by $\mathrm{GA}_{3}$ concentration and spray date. Evaluation date: 5 Mar. 1994.

injury from low temperatures.

$\mathrm{GA}_{3}$ application in November, when buds had only one to three secondary axis inflorescence meristems without apical bracts, resulted in production of vegetative shoots or partially formed inflorescences (with fewer secondary axes). Stimulation of the growth of the vegetative primary axis meristem by $\mathrm{GA}_{3}$ arrested the growth of secondary axis meristems adjacent to it, and the response was stronger at higher $\mathrm{GA}_{3}$ concentrations. However, flowering was not fully inhibited, demonstrating that $\mathrm{GA}_{3}$ did not revert secondary axis meristems into vegetative ones. Aborted meristems could be observed after inflorescence elongation as scars with small inflorescence bracts. In December, when buds with up to 10 secondary axis meristems (Stage 4; Salazar-García et al., 1998), some of which had one pair of bracts formed, were present, application of $\mathrm{GA}_{3}$ resulted in faster development of complete inflorescences. The response of 'Hass' avocado to earlier $\mathrm{GA}_{3}$ sprays deserves further investigation, since no $\mathrm{GA}_{3}$ treatment was applied before the beginning of inflorescence initiation in this study.

No signs of toxicity were observed for any $\mathrm{GA}_{3}$ concentration evaluated. $\mathrm{GA}_{3}$ at 50 and $100 \mathrm{mg} \cdot \mathrm{L}^{-1}$ had no negative morphological effects. However, $\mathrm{GA}_{3}$ at $1000 \mathrm{mg} \cdot \mathrm{L}^{-1}$ applied for all treatment dates caused a remarkable elongation of inflorescence axes, which in general appeared too weak to support setting fruit. Despite this axis elongation, individual flowers produced with $1000 \mathrm{mg} \cdot \mathrm{L}^{-1}$ $\mathrm{GA}_{3}$ were not elongated but rather they were smaller than control flowers.

The most often reported effects of $\mathrm{GA}_{3}$ on the physiology of flowering in deciduous fruit crops (Sedgley, 1990), citrus (Davenport, 1990), and mango (Kachru et al., 1972; Nunez-Elisea and Davenport, 1991) are inhibition of flower initiation and delay of flowering. However, in strawberry and coffee $\mathrm{GA}_{3}$ also accelerated the appearance of flowers that were differentiated at the time of application, resulting in early anthesis (Porlingis and Boynton, 1961; Schuch et al., 1990). For the $\mathrm{GA}_{3}$ spray dates and rates tested in our study, $\mathrm{GA}_{3}$ never delayed flowering, but hastened the flowering process of 'Hass' avocado. This is the first report of advanced flowering caused by $\mathrm{GA}_{3}$ on the avocado.

Under the climatic conditions of California, vegetative growth and leaf expansion of indeterminate inflorescences of 'Hass' avocado is delayed relative to the elongation of the secondary axes of the inflorescence. $\mathrm{GA}_{3}$ application dramatically increased the rate of development of the vegetative shoot at the apex of indeterminate inflorescences relative to elongation of the secondary axes of the inflorescence. The degree of precociousness was higher with both higher $\mathrm{GA}_{3}$ concentrations and later application dates, which was probably related to presence of warmer day temperatures during the late winter-early spring. A common hypothesis in the literature to explain low fruit set in avocado is that there may be a competition between the vegetative shoot that is developing at the time that the flowers of indeterminate inflorescences are setting fruit (Bower and Cutting, 1992; Cutting and Bower, 1990; Whiley, 1990; Zilkah et al., 1987). The precocious vegetative shoot development in indeterminate inflorescences caused by $\mathrm{GA}_{3}$ sprays might result in more successful inflorescences in terms of fruit set and yield by eliminating the competition between reproductive and vegetative growth. Leaves of the precocious vegetative shoot of indeterminate inflorescences treated with $\mathrm{GA}_{3}$ were sufficiently mature to be sources (based on net $\mathrm{CO}_{2}$ assimilation rates) at the time of fruit set (Blanke and Lovatt; personal communication, 1995).

Summer and fall flush shoots had a similar rate of inflorescence development and although some fall flush shoots started anthesis earlier than summer shoots, the date for full bloom was not different. Similar results for 'Hass' avocado in Australia were reported by Thorp et al. (1993). The absence of significant differences in the type of growth produced by apical buds of summer and fall flush shoots in response to $\mathrm{GA}_{3}$ sprays, suggests that a uniform response to $\mathrm{GA}_{3}$ application to entire trees might be achieved regardless of the relative size of the summer vs. fall flushes. However, responses to whole-tree application of $\mathrm{GA}_{3}$ must be quantified before this growth regulator can be recommended on a commercial scale in avocado. In particular, the possible effect of $\mathrm{GA}_{3}$ on excessive shoot elongation should be evaluated.

A pool of determinate and indeterminate inflorescences showed that fruit set was not influenced by the time of flowering. Nonetheless, fruit set was better on early flowering indeterminate inflorescences and better on late flowering determinate inflorescences. These results reflect the fact that early flowering inflorescences were mainly indeterminate, whereas late ones were mainly determinate. Thus, compared to indeterminate inflorescences, fruit set on determinate inflorescences occurs under warmer conditions,

Table 4. Fruit set by a pool of determinate and indeterminate 'Hass' avocado inflorescences during the early and late part of the 1994 flowering season (inflorescences were tagged at the cauliflower stage).

\begin{tabular}{lcc}
\hline & \multicolumn{2}{c}{ Evaluation time } \\
\cline { 2 - 3 } $\begin{array}{l}\text { Time of bloom } \\
\text { (cauliflower stage) }\end{array}$ & $\begin{array}{c}\text { After June drop } \\
\text { (8 Aug. 1994) }\end{array}$ & At physiological maturity \\
\hline & Fruit set/50 & (8 Dec. 1994) \\
\hline Early (12 Feb. 1994) & $0.91 \pm 0.18 \mathrm{a}^{\prime}$ & $0.86 \pm 0.17 \mathrm{a}$ \\
Late (12 Mar. 1994) & $0.95 \pm 0.16 \mathrm{a}$ & $0.88 \pm 0.16 \mathrm{a}$
\end{tabular}

${ }^{\mathrm{z}}$ Mean separation in columns by $t$ test, $P=0.05$.

Table 5. Time of flowering and final fruit set by determinate and indeterminate 'Hass' avocado inflorescences for the 1994 flowering season.

\begin{tabular}{lcc}
\hline Time of bloom & \multicolumn{2}{c}{ Type of inflorescence } \\
\cline { 2 - 3 } (cauliflower stage) & Determinate & Indeterminate \\
\hline Early (12 Feb. 1994) & $0.39 \pm 0.13 \mathrm{~b}^{2}$ & $0.49 \pm 0.10 \mathrm{a}$ \\
Late (12 Mar. 1994) & $0.59 \pm 0.12 \mathrm{a}$ & $0.29 \pm 0.08 \mathrm{~b}$
\end{tabular}

${ }^{2}$ Mean separation in columns by $t$ test, $P=0.10$. 
Table 6. Production of determinate and indeterminate inflorescences and contribution of each type of inflorescence to yield of 'Hass' avocado trees during the 1995 flowering season.

\begin{tabular}{lcc}
\hline & \multicolumn{2}{c}{ Type of inflorescence } \\
\cline { 2 - 3 } Characteristic evaluated & Determinate & Indeterminate \\
\hline Number of inflorescences/1-m-long branch (11 Apr. 1995) & $1.8 \pm 0.41 \mathrm{~b}^{7}$ & $10.3 \mathrm{~b}$ \\
Percentage total inflorescences & $120.4 \pm 6.7 \mathrm{a}$ & $89.7 \mathrm{a}$ \\
Number of flowers/inflorescence & $0.3 \pm 0.08 \mathrm{~b}$ & $105.2 \pm 6.2 \mathrm{a}$ \\
Number of mature fruit/l-m-long branch & $15.8 \mathrm{a}$ & $0.8 \pm 0.12 \mathrm{a}$ \\
Number of mature fruit/100 inflorescences & $0.17 \mathrm{a}$ & $5.1 \mathrm{~b}$ \\
Percentage fruit set (fruit/flower) & $27.3 \mathrm{~b}$ & $0.05 \mathrm{~b}$ \\
Contribution to yield $\%$ ) & $72.7 \mathrm{a}$ \\
\hline
\end{tabular}

${ }^{\mathrm{Z}}$ Mean $\pm \mathrm{SE}$ (where shown) separation in rows by $t$ test, $P=0.05$. Number of flowers/inflorescence was analyzed with the Mann-Whitney rank sum test.

which are more conducive for fruit set and initial fruit development (Lovatt 1990). This may indicate that the greater productivity of determinate inflorescences of 'Hass' avocado is not only due to the lack of competition from a developing vegetative apex, but also to their development in warmer, more favorable temperatures.

The higher proportion of indeterminate $(90 \%)$ vs. determinate (10\%) inflorescences found in this study of 'Hass' avocado (Table 6) agrees with the report by Thorpet al. (1994) for the same cultivar growing in Australia (65\% indeterminate inflorescences). In addition, our results were in the range reported for Schroeder (1944) for most avocado cultivars studied in California ( $80 \%$ to $95 \%$ of total inflorescences were indeterminate). In our study, determinate inflorescences had a much higher percentage of fruit set per flower $(0.17 \%)$ than indeterminate $(0.05 \%)$ inflorescences. The percentage of fruit set was close to the range previously reported for avocado $(0.02 \%$ to $0.1 \%$ ) (Chandler, 1958; Bergh, 1967). Given the predominance of indeterminate inflorescences and their low percent fruit set, eliminating the competition between vegetative and reproductive growth in these inflorescences by foliar application of $\mathrm{GA}_{3}$ might provide a management strategy to increase yield. In light of this possibility and due to the absence of any observed negative effects, foliar $\mathrm{GA}_{3}$ application warrants further investigation as a tool to increase fruit set and yield in a commercial avocado orchard.

\section{Literature Cited}

Bergh, B.O. 1967. Reasons for low yields of avocados. Calif. Avo. Soc. Yrbk. 51:161-172.

Bower, J.P. and J.G.M. Cutting. 1992. The effect of selective pruning on yield and fruit quality in 'Hass' avocado. Acta Hort. 296:55-58.

Chandler, W.H. 1958. Evergreen orchards. 2nd ed. Lea and Febiger, Philadelphia. p. 205-228.

Cutting, J.G.M. and I.P. Bower. 1990. Relationship between auxin transport and calcium allocation in vegetative and reproductive flushes in avocado. Acta Hort. 275:469 475 .

Davenport, T.L. 1982. Avocado growth and development. Proc. Fla. State Hort. Soc. 95:92-96.

Davenport, T.L. 1990. Citrus flowering. Hort. Rev. 12:349-408.

Guardiola, J.L., M. Agustí, and F. García-Marí. 1977. Gibberellic acid and flower bud development in sweet orange. Proc. Intl. Soc. Citricult. 2:696-699.

Iwahori, S. and J.T. Oohata. 1981. Control of flowering of Satsuma mandarins (Citrus unshiu Marc) with gibberellin. Proc. Int. Soc. Citricult. 1:247-249.
Kachru, R.B., R.N. Singh, and E.K. Chacko. 1972. Inhibition of flowering in Mangifera indica L. by gibberellic acid. Acta Hort. 24:206-209.

Lovatt, C.J. 1990. Factors affecting fruit set/early fruit drop in avocado. Calif. Avo. Soc. Yrbk. 74:193-199.

Nir, I., R. Goren, and B. Leshem. 1972. Effects of water stress, gibberellic acid and 2-chloroethyltrimethylammoniumchloride (CCC) on flower differentiation in 'Eureka' lemon trees. J. Amer. Soc. Hort. Sci. 97:774778.

Nunez-Elisea, R. and T.L. Davenport. 1991. Flowering of 'Keitt' mango in response to deblossoming and gibberellic acid. Proc. Fla. State Hort. Soc. 104:41-43.

Porlingis, I.C. and D. Boynton. 1961. Growth responses of the strawberry plant, Fragaria chiloensis var. ananassa, to Gibberellic acid and to environmental conditions. Proc. Amer. Soc. Hort. Sci. 78:261-269.

Salazar-García, S., E.M. Lord, and C.J. Lovatt. 1998. Inflorescence and flower development of the 'Hass' avocado (Persea americana Mill.) during "on" and "off" crop years. J. Amer. Soc. Hort. Sci. (in press).

Scholefield, P.B., M. Sedgley, and D.Mc.E. Alexander. 1985. Carbohydrate cycling in relation to shoot growth, floral initiation and development and yield in the avocado. Scientia Hort. 25:99-110.

Schroeder, C.A. 1944. The avocado inflorescence. Calif. Avo. Soc. Yrbk. 28:39-40.

Schuch, U.K., L.H. Fuchigami, and M.A. Nagao. 1990. Gibberellic acid causes earlier flowering and synchronizes fruit ripening in coffee. Plant Growth Regulat. 9:59-64.

Sedgley, M. 1990. Flowering of deciduous perennial fruit crops. Hort. Rev. 12:223-264.

Steel, R.G.D. and J.H. Torrie. 1980. Principles and Procedures of Statistics. A Biometrical approach. 2nd ed. McGraw-Hill.

Thorp, T.G., D. Aspinall, and M. Sedgley. 1993. Influence of shoot age on floral development and early fruit set in avocado (Persea americana Mill.) cv. 'Hass'. J. Hort. Sci. 68:645 651.

Thorp, T.G., D. Aspinall, and M. Sedgley. 1994. Preformation of node number in vegetative and reproductive proleptic shoot modules of Persea (Lauraceae). Ann. Bot. 73:13-22.

Venning, F.O. and F.B. Lincoln. 1958. Developmental morphology of the vegetative axis of avocado (Persea americana $\mathrm{L}$.) and its significance to spacing, pruning practices, and yields of the grove. Proc. Fla. State Hort. Soc. 71:350--356.

Whiley, A.W. $1990 . \mathrm{CO}_{2}$ assimilation of developing fruiting shoots of $\mathrm{cv}$. Hass avocado (Persea americana Mill.) —A preliminary report. S. Afr. Avo. Grow. Assn. Yrbk. 13:28-30.

Zilkah, S., I. Klein, S. Feigenbaum, and S.A. Weinbaum. 1987. Translocation of foliar-applied urea ${ }^{15} \mathrm{~N}$ to reproductive and vegetative sinks of avocado and its effects on initial fruit set. J. Amer. Soc. Hort. Sci. 112: 1061-1065. 